\title{
Surveilans Aedes aegypti di Daerah Endemis Demam Berdarah Dengue
}

\section{Aedes aegypti Surveillance in Endemic Area of Dengue Haemorrhagic Fever}

\author{
Sunaryo, Nova Pramestuti
}

Balai Penelitian dan Pengembangan Pengendalian Penyakit Bersumber Binatang Banjarnegara

\begin{abstract}
Abstrak
Demam Berdarah Dengue (DBD) perlu mendapat perhatian serius karena masih menjadi masalah kesehatan di Indonesia dan di beberapa daerah masih sering terjadi kejadian luar biasa. Di Jawa Tengah, kasus DBD cenderung meningkat setiap tahunnya terutama pada tahun 2012. Penelitian ini bertujuan menganalisis parameter entomologi dan menggambarkan jenis tempat penampungan air. Penelitian dilakukan di Kabupaten Grobogan, Purbalingga, Kendal dan Kota Semarang pada bulan Juni - Oktober 2013 dengan desain potong lintang. Survei jentik dilakukan untuk melihat keberadaan tempat penampungan air pada 100 rumah. Masing-masing kabupaten dipilih tiga lokasi desa endemis DBD. Hasil survei digunakan untuk menghitung nilai parameter entomologi. Hasil penelitian menunjukkan bahwa meningkatnya kasus DBD di empat kabupaten/kota terkait dengan keberadaan vektor $A$. aegypti. Hal ini dibuktikan dengan masih tingginya persentase jumlah rumah yang ditemukan jentik $A$. aegypti (House Index > $10 \%$ ) serta tingginya jumlah kontainer ditemukan jentik $A$. aegypti pada rumah yang dilakukan survei (Breteau Index). Nilai ovitrap index paling tinggi di Desa Kalikabong Kabupaten Purbalingga seesar 40\%. Proporsi controllable site lebih banyak daripada disposable site, berarti rumah tersebut berisiko tinggi sebagai tempat perkembangbiakan nyamuk.

Kata kunci: Aedes aegypti, Demam Berdarah Dengue, surveilans
\end{abstract}

\section{Abstract}

Dengue Haemorrhagic Fever (DHF) needs serious attention because it is still a health problem in Indonesia and in recent area DHF caused outbreak. In Central Java, incidence of DHF high every years, especially in 2012. This study aimed to analyze the parameters of entomology and describe types of containers. The study was conducted in Grobogan, Purbalingga, Kendal District and Semarang City in June - October 2013 with cross-sectional design. Larvae survey had been done in 100 houses in three villages that endemic DHF at every district/city. The survey results are used to calculate parameter entomology. The results showed that existance of DHF cases in four district/city connected with the population of $A$. aegypti. This matter proved with high percentage of houses that found $A$. aegypti (House Index $>10 \%$ ) and the high of container that containing $A$. aegypti in every houses (Breteau Index). The high of ovitrap index (OI) was $40 \%$ in Kalikabong village, Purbalingga district. The proportion of controllable sites more than disposable sites, meaning the house as the high risk of mosquito breeding sites.

Keywords: Aedes aegypti, Dengue Haemorrhagic Fever, surveillance

\section{Pendahuluan}

Angka kesakitan Demam Berdarah Dengue (DBD) per 100.000 penduduk di Jawa Tengah lima tahun terakhir adalah 59,2 pada tahun 2008; 57,9 pada tahun 2009; 56,8 pada tahun 2010; 15,3 pada tahun 2011; dan 19,29 pada tahun 2012. Penyebarannya tidak hanya terjadi pada daerah perkotaan, tetapi sudah menyebar ke daerah perdesaan. Sejak tahun 2007, 33 kabupaten/kota dari 35 kabupaten/kota di Jawa Tengah merupakan daerah endemis DBD. Pada tahun 2008 - 2009, sudah menyebar ke seluruh kabupaten/kota dengan jumlah kasus yang cukup tinggi. Pada tahun 2010 - 2011, semua wilayah mengalami penurunan kasus DBD. ${ }^{1}$

Perubahan lingkungan global atau Global Environmental Change (GEC) terutama Global Warming sedikit banyak ikut berperan terhadap kejadian DBD. Setiap peralihan musim, terutama dari musim kemarau ke musim penghujan, berbagai masalah kesehatan melanda termasuk yang paling sering terjadi adalah peningkatan

Alamat Korespondensi: Sunaryo, Balai Penelitian dan Pengembangan Pengendalian Penyakit Bersumber Binatang Banjarnegara, Jl. Selamanik No. 16A Banjarnegara, Hp.08122754138, e-mail: yok_ban@yahoo.com 
kejadian demam berdarah. Faktor risiko lain infeksi dengue diantaranya tingkat imunitas host, kepadatan penduduk, interaksi vektor dan host dan virulensi virus. Kepadatan vektor juga berkontribusi terhadap epidemi DBD. ${ }^{2}$

Berbagai upaya telah dilakukan oleh instansi kesehatan untuk memutus rantai penularan demam berdarah di antaranya dengan penemuan dan pengobatan penderita, pengendalian vektor dan kerja sama lintas sektor. Kegiatan pengendalian vektor yang pernah dilaksanakan yaitu pengasapan (fogging) dan kegiatan pemberantasan sarang nyamuk (PSN) dengan melibatkan peran serta masyarakat. ${ }^{3}$ Pengamatan vektor Aedes aegypti sangat penting terutama untuk mengetahui penyebaran, kepadatan, habitat utama larva/jentik, kemungkinan risiko terjadinya penularan, tingkat kepekaan nyamuk terhadap insektisida dan memprioritaskan lokasi serta waktu pelaksanaan pemberantasan vektor. ${ }^{4}$

Keberadaan jentik Aedes aegypti di suatu daerah merupakan indikator terdapatnya populasi nyamuk Aedes aegypti di daerah tersebut. Upaya pengendalian vektor DBD paling efektif dengan Pemberantasan Sarang Nyamuk Demam Berdarah Dengue (PSN-DBD). ${ }^{5}$ Data tentang populasi vektor DBD di setiap wilayah, seperti Container Index (CI), House Index (HI), Breteau Index (BI), Pupae Index (PI) dan Ovitrap Index (OI) yang menjadi parameter entomologis sangat diperlukan.

Dalam konteks penanggulangan DBD, juga diperlukan data lingkungan terkait dengan segi bionomik nyamuk vektor DBD, yaitu Maya Index (MI). Bionomik merupakan hubungan antara aktivitas dan perilaku nyamuk dalam kesehariannya dengan lingkungan. MI digunakan dalam upaya pengendalian DBD di suatu daerah. Dengan MI, bisa diketahui tingkat risiko perkembangbiakan jentik yang berguna untuk menentukan prioritas dalam penyusunan program pengendalian larva. Selain itu, dapat diketahui tempat perkembangbiakan yang paling disukai sebagai acuan dalam program pengendalian larva nyamuk. 6

Penelitian ini bertujuan untuk menganalisis parameter entomologi (House Index/HI, Breteau Index/BI, Container Index/CI, Pupae Index/PI, Ovitrap Index/OI) dan menggambarkan jenis tempat penampungan air (TPA) di lokasi penelitian yang menunjukkan tingkat risiko penularan DBD.

\section{Metode}

Penelitian ini dilakukan di empat kabupaten/kota di Jawa Tengah yang merupakan wilayah endemis DBD yaitu Kabupaten Grobogan, Purbalingga, Kendal, dan Kota Semarang. Waktu penelitian selama enam bulan (Juni - November 2013). Penelitian ini menggunakan desain potong lintang (cross sectional). Unit analisis adalah individu vektor $A$. aegypti dari lokasi penelitian. Unit sampling pada penelitian ini adalah rumah-rumah penduduk. Besar sampel rumah penelitian adalah 100 rumah per desa, setiap kabupaten sebanyak 3 desa yang merupakan desa endemis DBD tinggi. Rumah sampel diambil secara purposif dari populasi rumah yang ada di wilayah desa. Larva $A$. aegypti diambil dari tempat penampungan air (TPA) di dalam dan di sekitar rumah menggunakan metode visual. TPA dibedakan menjadi controlable sites dan disposable sites. Controlable sites merupakan TPA yang masih digunakan dalam keperluan sehari-hari yang dapat dimanipulasi keberadaannya agar tidak menjadi tempat perkembangbiakan nyamuk, sedangkan disposable sites merupakan barang-barang yang sudah tidak terpakai, baik dalam keadaan terisi air maupun kering, yang berpotensi sebagai TPA bila musim hujan tiba. ${ }^{7}$ Alat yang digunakan adalah pipet/alat penyedot jentik, vial botol, kertas label dan form survei jentik. Survei telur dilakukan dengan pemasangan ovitrap pada masing-masing rumah sebanyak 2 ( 1 di dalam dan 1 di luar rumah). Ovitrap diambil 4 hari setelah pemasangan.

\section{Hasil}

Kasus DBD di Provinsi Jawa Tengah masih menjadikan permasalahan yang cukup serius. IR (Incidence Rate) DBD di Provinsi Jawa Tengah selama tiga tahun terakhir menunjukkan peningkatan, yaitu tahun 2011 sebesar 15,3 per 100.000 penduduk, tahun 2012 meningkat sebesar 19,29 per 100.000 penduduk dan mengalami peningkatan juga pada tahun 2013 sebesar 38,3 per 100.000 penduduk.

Gambar 1 menunjukkan bahwa sebanyak 25 kabupaten $(75 \%)$ merupakan kabupaten dengan IR DBD lebih dari 20 per 100.000 penduduk sedangkan angka IR kabupaten lainnya (25\%) kurang dari 20 per 100.000 penduduk. Empat kabupaten yang menjadi target penelitian ini termasuk 25 kabupaten dengan IR lebih dari 20 per 100.000 penduduk. Kabupaten tersebut adalah Kabupaten Kendal dengan IR sebesar 43,61 per 100.000 penduduk, Kota Semarang sebesar 123,75 per 100.000 penduduk, Kabupaten Purbalingga sebesar 60,28 per 100.000 penduduk, dan Kabupaten Grobogan sebesar 40,71 per 100.000 penduduk.

Penularan kasus DBD dari tahun ke tahun masih mengambarkan pola yang sama yaitu meningkat pada awal musim penghujan atau sekitar bulan Januari sampai Mei. Pada bulan Desember secara umum kasus meningkat lagi (Gambar 2).

Hasil survei entomologi di Kabupaten Kendal, Kabupaten Purbalingga, Kabupaten Grobogan dan Kota Semarang dapat dilihat pada Tabel 1 yang menunjukkan bahwa angka HI di semua desa cukup tinggi yaitu di atas $10 \%$. Parameter HI tertinggi di Kabupaten Grobogan yaitu mencapai angka di atas $60 \%$, sedangkan $\mathrm{HI}$ rendah di Kota Semarang antara $13-28 \%$. Angka CI tertinggi 

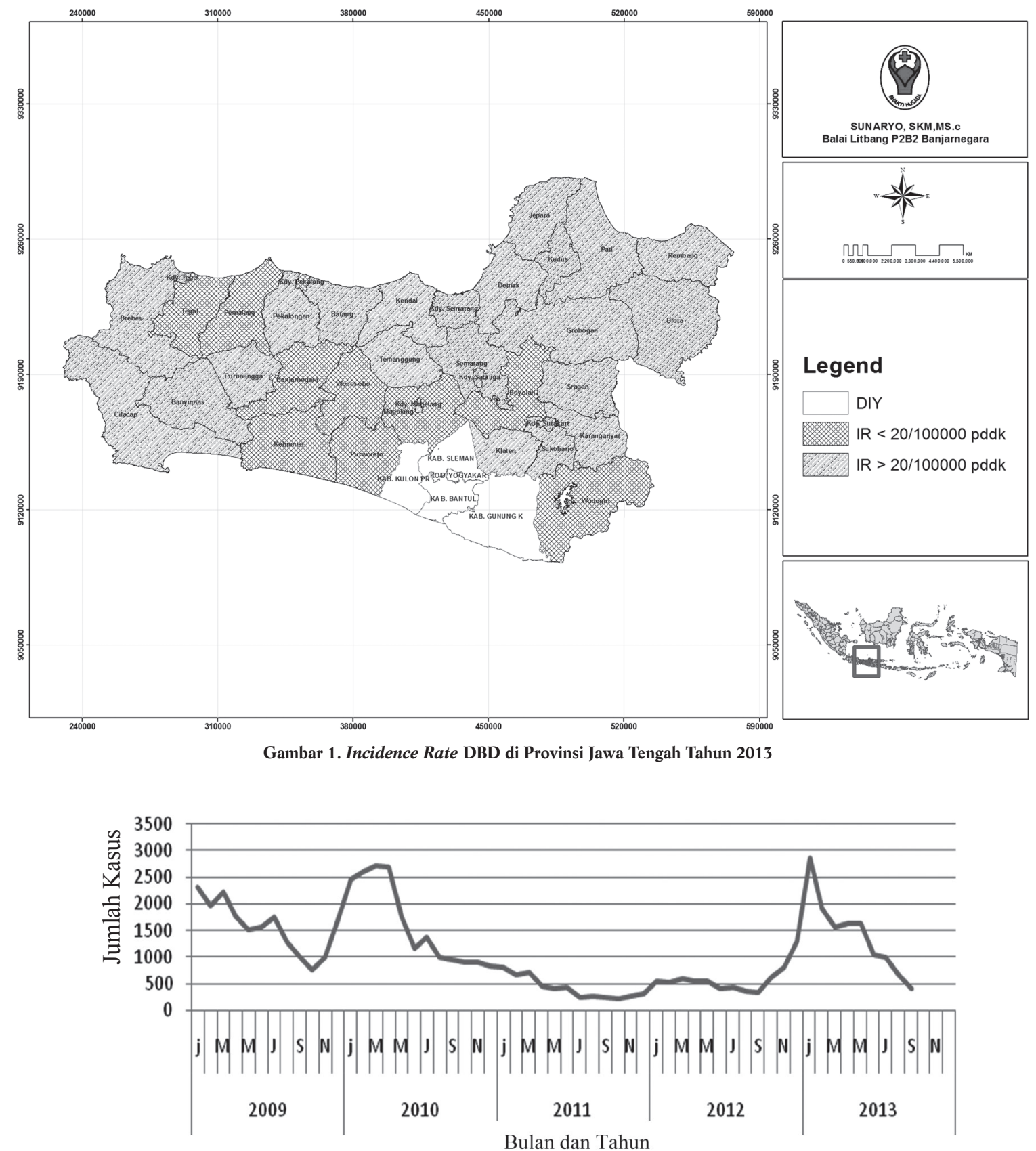

Gambar 2. Pola Fluktuasi Kasus DBD di Jawa Tengah Tahun 2009-2013

juga di wilayah Grobogan di atas 45\%, sedangkan CI rendah di Kota Semarang di bawah 10\%. Nilai BI yang tinggi di Kabupaten Grobogan mencapai 157. Beberapa catatan di daerah Grobogan merupakan daerah yang tergolong sulit air pada musim kemarau sehingga ada beberapa upaya menampung air dengan beberapa kontainer di dalam rumah. Kondisi yang demikian juga berpengaruh terhadap keberadaan jentik yang bisa berkembang biak dengan sempurna. Hal ini terlihat juga dengan tingginya angka pupa indeks di wilayah tersebut, yaitu mencapai 168.
Semua lokasi penelitian memiliki nilai HI melebihi ambang batas parameter entomologi $(\mathrm{HI}>10 \%)$. Hal ini mengindikasikan bahwa daerah tersebut sensitif dan rawan terhadap DBD (Gambar 3).

Dari kegiatan pemasangan ovitrap pada 100 rumah di masing-masing desa diperoleh jumlah telur terbanyak di wilayah Kabupaten Purbalingga terutama di desa Kalikabong yaitu $40 \%$ ovistrip terdapat telur A.aegypti sebanyak 1.190 butir (Tabel 2).

Tabel 3 menunjukkan jenis kontainer berupa Controllable Sites (CS) dan Disposable Site (DS) positif jentik 
Tabel 1. Parameter Entomologi di Kabupaten Grobogan, Kendal, Purbalingga, dan Kota Semarang

\begin{tabular}{lllllll}
\hline Kabupaten/Kota & Desa & HI (\%) & CI (\%) & BI & PI & ABJ (\%) \\
\hline \multirow{2}{*}{ Grobogan } & Dayang & 65 & 51,33 & 116 & 168 & 35 \\
& Jono & 61 & 58,58 & 157 & 10 & 39 \\
\multirow{3}{*}{ Kendal } & Pulo kulon & 74 & 46,59 & 130 & 30 & 26 \\
& Tambak Rejo & 36 & 20,1 & 41 & 22 & 64 \\
& Kebon Harjo & 39,61 & 25,97 & 40,82 & 10,2 & 60,39 \\
Purbalingga & Langen Harjo & 35 & 24,85 & 42 & 33 & 65 \\
& Kalikabong & 18 & 9,36 & 28 & 5 & 82 \\
& Penaruban & 28 & 20,92 & 41 & 12 & 72 \\
Semarang & Purbalingga Wetan & 17 & 11,49 & 17 & 6 & 83 \\
& Tembalang & 13 & 5,42 & 16 & 7 & 87 \\
& Gunungpati & 27,55 & 4,92 & 13,27 & 5,05 & 72,45 \\
& Sampangan & 31 & 22,16 & 37 & 36 & 69 \\
\hline
\end{tabular}

Keterangan:

$\mathrm{HI}=$ House Index, $\mathrm{CI}=$ Container Index, $\mathrm{BI}=$ Breteau Index, $\mathrm{PI}=$ Pupa Index, $\mathrm{ABJ}=$ Angka Bebas Jentik

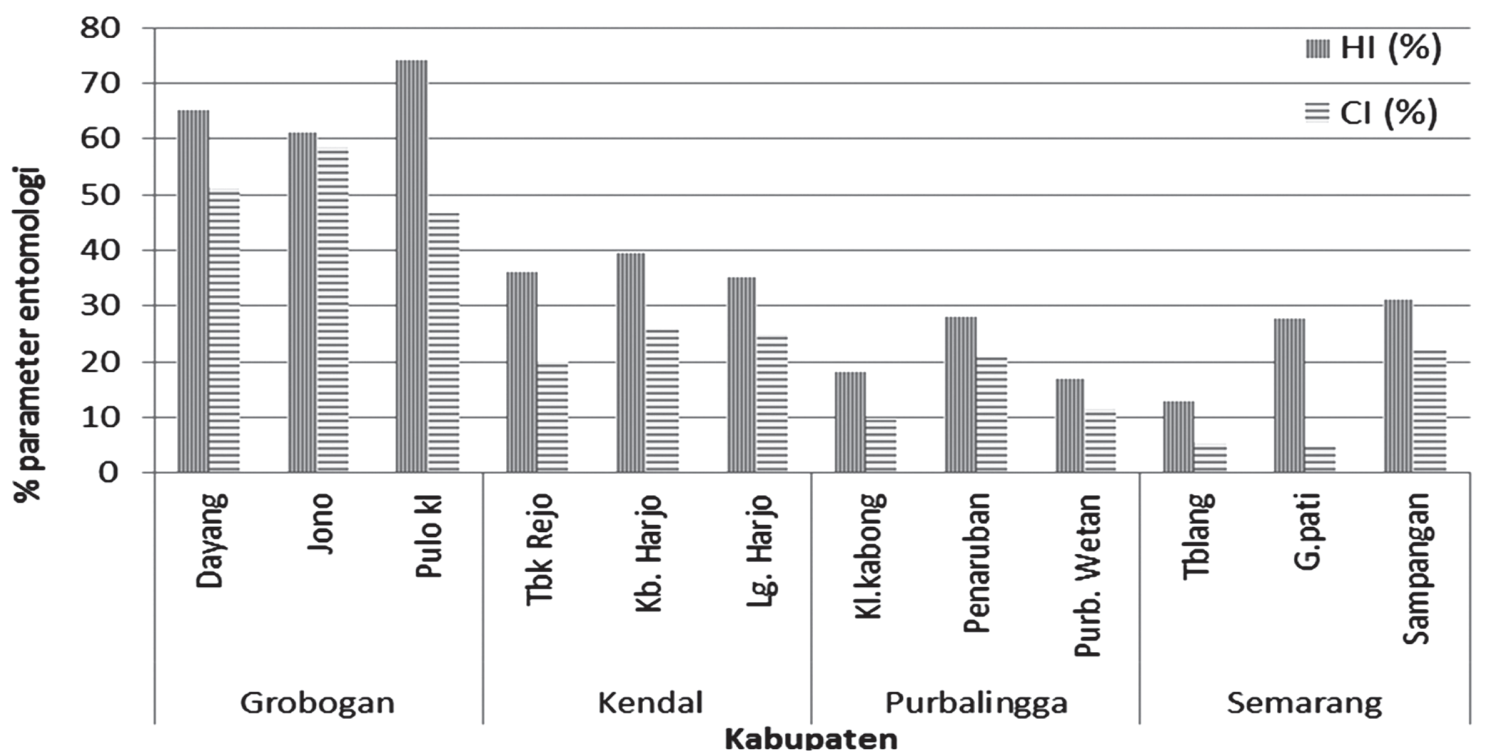

Gambar 3. Persentase Ambang Batas Parameter Entomologi terhadap Risiko Penularan DBD Menurut WHO

Tabel 2. Jumlah Ovistrip dan Telur Hasil Pemasangan Ovitrap

\begin{tabular}{llll}
\hline Kota/kabupaten & Desa & Strip (lembar) & Telur (butir) \\
\hline Purbalingga & Purbalingga Wetan & 20 & 654 \\
& Penaruban & 6 & 135 \\
Grobogan & Kalikabong & 40 & 1.190 \\
& Jono & 3 & 41 \\
& Dayang & 18 & 384 \\
Kota Semarang & Pulo Kulon & 7 & 122 \\
& Tembalang & 8 & 15 \\
Kendal & Gunungpati & 5 & 18 \\
& Sampangan & 20 & 109 \\
& Langen harjo & 16 & 72 \\
& Tambakrejo & 10 & 28 \\
& Kebonharjo & 10 & 28 \\
\hline
\end{tabular}

yang potensial menjadi tempat perkembangbiakan nyamuk A. aegypti di Kabupaten Grobogan, Kendal, Purbalingga, dan Kota Semarang. Bak mandi dan ember merupakan kontainer yang ditemukan pada keempat lokasi penelitian. Jenis kontainer lebih proporsi controllable site dengan positif jentik lebih banyak dijumpai yakni sebesar $82 \%$ daripada proporsi disposable site $(18 \%)$.

\section{Pembahasan}

Kasus DBD di Provinsi Jawa Tengah selalu meningkat dari tahun ke tahun, baik dalam hal jumlah maupun persebaran wilayahnya. Walaupun secara umum persebaran kasus masih didominasi di wilayah perkotaan, namun pada perkembangannya kasus DBD sudah mulai merambah ke perdesaaan sebagaimana yang terjadi di Kabupaten Purbalingga. Menurut Dinas Kesehatan Provinsi Jawa Tengah, dalam analisis situasi DBD, peningkatan kasus DBD disebabkan oleh pertambahan penduduk, perkembangan wilayah dari sebuah desa menjadi kota, perpindahan penduduk dan penataan kota dan struktur bangunan yang kurang memperhatikan unsur 
Tabel 3. Berbagai Jenis Kontainer Positif Ditemukan Jentik A.aegypti

\begin{tabular}{|c|c|c|c|c|}
\hline \multirow{2}{*}{ Jenis Kontainer } & \multicolumn{4}{|c|}{ Kabupaten/Kota } \\
\hline & Purbalingga & Grobogan & Kendal & Semarang \\
\hline \multicolumn{5}{|l|}{ Controllable Site } \\
\hline Bak mandi & $\mathrm{V}$ & $\mathrm{V}$ & $\mathrm{V}$ & V \\
\hline Bak wc & $\mathrm{V}$ & $\mathrm{V}$ & $\mathrm{V}$ & \\
\hline Tandon/penampungan air & & $\mathrm{V}$ & $\mathrm{V}$ & $\mathrm{V}$ \\
\hline Belakang kulkas & $\mathrm{V}$ & & & $\mathrm{V}$ \\
\hline Dispenser & V & & & $\mathrm{V}$ \\
\hline Drum & & $\mathrm{V}$ & & \\
\hline Ember & $\mathrm{V}$ & V & $\mathrm{V}$ & $\mathrm{V}$ \\
\hline \multicolumn{5}{|l|}{ Galon } \\
\hline Gentong & & V & $\mathrm{V}$ & $\mathrm{V}$ \\
\hline Kolam ikan & & & $\mathrm{V}$ & $\mathrm{V}$ \\
\hline Pot bunga & V & & $\mathrm{V}$ & \\
\hline Sumur & & & $\mathrm{V}$ & \\
\hline Tong air & & $\mathrm{V}$ & & \\
\hline Tempat air wudhu & & V & V & \\
\hline Tempayan & & & $\mathrm{V}$ & $\mathrm{V}$ \\
\hline \multicolumn{5}{|l|}{ Disposable Site } \\
\hline Ban bekas & $\mathrm{V}$ & & & $\mathrm{V}$ \\
\hline Ember bekas & & & & V \\
\hline Tempat mainan & V & & & \\
\hline Kaleng bekas & $\mathrm{V}$ & & & \\
\hline Baskom bekas & V & & & \\
\hline
\end{tabular}

kesehatan. ${ }^{1}$ Pola kasus DBD meningkat pada awal tahun sampai pertengahan tahun, tetapi sampai akhir tahun menurun. Pola ini sejalan dengan pola curah hujan yang tinggi pada awal sampai pertengahan tahun. Hal ini sejalan dengan penelitian Pramestuti, ${ }^{8}$ bahwa pada kenaikan jumlah kasus DBD sinergis dengan kenaikan curah hujan.

Peningkatan kasus DBD di beberapa tempat di Provinsi Jawa Tengah tidak lepas dari keberadaan nyamuk A.aegypti sebagai vektor penular. Kepadatan larva A. aegypti akan meningkat pada saat musim penghujan tiba sampai menjelang akhir musim penghujan. Kondisi tersebut disebabkan keberadaan kontainer berisi air di luar rumah yang bertambah. Beberapa parameter entomologi untuk mengetahui pada suatu daerah dinyatakan rawan atau aman terhadap DBD diantaranya Pant dan Self, ${ }^{9}$ yang disitasi oleh Kharis Ma'mun membuat suatu pedoman batas ambang indeks larva untuk menentukan risiko penularan berdasarkan nilai Breteau Index (BI) dan House Index $(\mathrm{HI})$ yaitu $\mathrm{BI}>50$ berarti risiko penularan tinggi, $\mathrm{BI}<5$ berarti risiko penularan rendah, $\mathrm{HI}>10 \%$ berarti risiko penularan tinggi dan $\mathrm{HI}<1 \%$ berarti risiko penularan rendah. $\mathrm{HI}>5 \%$ dan atau $\mathrm{BI}>20$ mengindikasikan bahwa lokasi tersebut sensitif terhadap infeksi dengue dan dibutuhkan langkah-langkah pencegahan yang lebih memadai. ${ }^{10}$

Tingginya angka kepadatan larva ini karena kurangnya pengetahuan warga tentang tempat perkembangbiakan yang disukai nyamuk Aedes aegypti, serta kurangnya perhatian dari sebagian masyarakat terhadap pemeliharaan kebersihan tempat penampungan air dan kebersihan lingkungan sekitar. Keadaan ini akan memudahkan penyebaran penyakit DBD karena nyamuk Aedes aegypti mencari tempat yang sesuai untuk istirahat dan berkembang biak dan jarak tempat-tempat tersebut tidak melampui jarak terbangnya yaitu mencapai 40-100 meter dari tempat perkembangbiakannya. ${ }^{11}$

Menurut WHO, House Index (HI) merupakan indikator yang paling banyak digunakan untuk memonitor tingkat infestasi nyamuk. Namun, parameter ini termasuk lemah dalam risiko penularan penyakit apabila tidak menghitung TPA atau kontainer dan data rumah yang positif dengan larva/jentik. Nilai HI menggambarkan persentase rumah yang positif untuk perkembangbiakan vektor sehingga dapat mencerminkan jumlah populasi yang berisiko. ${ }^{9} \mathrm{HI}$ tidak memperhitungkan jumlah kontainer dengan nyamuk dewasa maupun produksi nyamuk dewasa dari kontainer tersebut. ${ }^{12}$ Bila suatu daerah mempunyai HI lebih dari 5\%, daerah tersebut mempunyai risiko tinggi untuk penularan dengue. Bila HI kurang dari $5 \%$, masih bisa dilakukan pencegahan untuk terjadinya infeksi virus dengue. Lebih lanjut dijelaskan bahwa bila HI $>15 \%$ berarti daerah tersebut sudah ada kasus DBD. Semakin tinggi angka HI, berarti semakin tinggi kepadatan nyamuk, semakin tinggi pula risiko masyarakat di daerah tersebut untuk kontak dengan nyamuk dan juga untuk terinfeksi virus dengue. ${ }^{13}$

Nilai CI dapat digunakan sebagai alat pembanding yang penting dalam mengevaluasi program pengendalian vektor, tetapi tidak begitu berguna dari sisi epidemiologis. Nilai CI menggambarkan banyaknya kontainer yang positif dibandingkan dengan jumlah seluruh kontainer yang terdapat di suatu wilayah karena hanya mengungkapkan persentase tempat penampungan air (TPA) atau kontainer yang positif dengan larva/jentik perkembangbiakan nyamuk Aedes sp. ${ }^{9} \mathrm{CI}$ memberikan informasi mengenai proporsi kontainer yang berisi $>1$ ekor nyamuk dewasa, tidak memperhitungkan variasi atau kepadatan nyamuk dewasa. ${ }^{12}$

Nilai BI menunjukkan hubungan antara kontainer yang positif dengan jumlah rumah. Indeks ini dianggap indeks yang paling baik, tetapi tidak mencerminkan jumlah larva/jentik dalam kontainer. Meskipun demikian, pada waktu pengumpulan data dasar untuk perhitungan BI akan didapatkan juga profil dan karakter habitat larva/ jentik, dengan cara sekaligus mencatat jumlah dan potensi dari semua macam tipe kontainer. ${ }^{14}$ Secara umum, BI merupakan indikator yang paling baik dibandingkan dengan CI dan HI karena mengkombinasikan antara tempat tinggal dan kontainer. Oleh karena itu, BI mempunyai nilai signifikan epidemologis yang lebih besar. ${ }^{9}$ Nilai BI tinggi berarti masih ditemui jumlah rumah dengan kontainer positif jenisnya lebih dari satu kontainer. BI membentuk hubungan antara kontainer yang positif dan rumah, tetapi juga tidak dapat memperhitungkan nyamuk 
dewasa dari kontainer. BI merupakan indikator yang lebih menggambarkan prevalensi daripada kelimpahan. ${ }^{12}$

Parameter entomologi HI, CI, dan BI memiliki relevansi langsung dengan dinamika penularan penyakit. Namun, tingkat ambang batas infestasi vektor yang merupakan pemicu untuk transmisi dengue dipengaruhi oleh banyak faktor, termasuk umur nyamuk dan status imunologi manusia. Sebagai contoh di Singapura, transmisi dengue terjadi bahkan ketika $\mathrm{HI}<2 \%$. Di Singapura, meskipun kepadatan vektor rendah melalui program pengendalian DBD/DSS wabah masih terjadi bahkan ketika $\mathrm{HI}$ turun menjadi $1 \%$. Karena, $\mathrm{HI}<1 \%$ atau $\mathrm{BI}<$ $5 \%$ ditujukan untuk mencegah penularan demam kuning, nilai-nilai ini juga telah diterapkan untuk penularan dengue tetapi tanpa bukti. Tingginya indeks perkembangbiakan larva Aedes di Kabupaten Thiruvananthapuram menunjukkan Aedes sebagai penular dengue dan wabah di masa depan seperti dalam studi-studi sebelumnya. ${ }^{15}$

Nilai OI paling tinggi di wilayah Kabupaten Purbalingga terutama di desa Kalikabong sebesar $40 \%$. Nilai ini termasuk dalam kategori level 4 (nilai OI $\geq 40 \%$ ). Tindakan pengendalian yang layak dilakukan untuk level 4 ini adalah penggunaan larvasida dan insektisida untuk nyamuk dewasa. ${ }^{16}$ Parameter OI lebih sensitif dibandingkan BI dalam mendeteksi keberadaan vektor. Secara umum ovitrap merupakan metode monitoring sederhana dan mudah karena jumlah telur yang diletakkan di perangkap standar dalam periode waktu tertentu akan memberikan ukuran relatif dari jumlah nyamuk di daerah yang sama. Oleh karena itu, disarankan bahwa pemasangan ovitrap di lokasi penelitian dapat menghasilkan monitoring yang efektif untuk keberadaan vektor dalam keadaan nilai BI rendah. Ovitrap tidak memberikan estimasi kepadatan populasi A. aegypti, tetapi dapat memberikan informasi perubahan relatif pada populasi nyamuk betina. ${ }^{2}$

Proporsi kontainer controllable site dalam penelitian ini lebih banyak daripada disposable site. Hal ini menunjukkan rumah tersebut berisiko tinggi sebagai tempat perkembangbiakan nyamuk. ${ }^{17}$ Berdasarkan hasil survei entomologi yang dilakukan di Kabupaten Grobogan, Kendal, Purbalingga, dan Kota Semarang terkait dengan penularan DBD, diperlukan suatu upaya melalui peran serta masyarakat. Kesadaran tentang lingkungan sudah selayaknya dimiliki oleh warga karena mencegah dan menanggulangi kejadian DBD bukan hanya tugas orang kesehatan semata namun juga peran serta masyarakat sangat dibutuhkan. Kelalaian masyarakat dalam mengelola lingkungan rumahnya terbukti dengan adanya jentik pada bak, ember, akuarium, wastafel, serta kontainer lain. Benda-benda tersebut sudah seharusnya dibersihkan secara rutin minimal seminggu sekali. Upaya lain yang perlu dilakukan adalah tindakan intervensi pengendalian vektor penular baik secara kimia, biologi, manajemen lingkungan, dan integrated vector management (IVM). Beberapa penelitian efek intervensi pengendalian vektor dengue terhadap parameter entomologi telah dilakukan dan dilakukan meta analisis. ${ }^{18}$ Intervensi pengendalian vektor secara kimia melalui penyemprotan di dalam dan luar rumah dengan insektisida, penggunaan larvasida yang diaplikasikan pada kontainer dan lethal ovitraps. Intervensi pengendalian vektor secara biologi melalui larvivorous fish, insects larvae, dan copepods.

\section{Kesimpulan}

Secara umum di Kabupaten Kendal, Kabupaten Purbalingga, Kabupaten Grobogan dan Kota Semarang nilai $\mathrm{HI}>10 \%$, CI antara 4,92-58,58\%, BI antara 13,27 157, PI antara 5 - 168. Nilai OI paling tinggi di Desa Kalikabong, Kabupaten Purbalingga sebesar $40 \%$. Proporsi controllable site lebih banyak daripada disposable site. Hal ini menunjukkan rumah tersebut berisiko tinggi sebagai tempat perkembangbiakan nyamuk.

\section{Saran}

Kegiatan pemberantasan sarang nyamuk perlu dilaksanakan secara rutin minimal seminggu sekali, mengingat persentase kepadatan jentik di setiap rumah cukup tinggi. Tindakan pengendalian vektor yang perlu dilakukan adalah penggunaan larvasida dan insektisida untuk nyamuk dewasa, terutama di Desa Kalikabong, Kabupaten Purbalingga karena nilai OI masuk dalam kategori level empat.

\section{Daftar Pustaka}

1. Dinas Kesehatan Provinsi Jawa Tengah. Situasi penyakit bersumber binatang di Jawa Tengah. Pertemuan Ilmiah Balai Litbang P2B2 Banjarnegara; 2012.

2. Ho CM, Feng CC, Yang CT, Lin MW, Tang Hc, Lin TS, et al. Surveillance for dengue fever vectors using ovitraps at Kaohsiung and Tainan in Taiwan. Formos Entomol. 2005; (25): 159-74.

3. Direktorat Jenderal Pengendalian Penyakit dan Penyehatan Lingkungan Departemen Kesehatan Republik Indonesia. Pencegahan dan pemberantasan demam berdarah Dengue di Indonesia. Jakarta: Direktorat Jenderal Pengendalian Penyakit dan Penyehatan Lingkungan Departemen Kesehatan Republik Indonesia; 2005.

4. Georghiou GP, Saito T, eds. Pest resistance to pesticides. New York: Plenum Press; 1983.

5. Widiarti, Heriyanto B, Boewono DT. Peta resistensi vektor demam berdarah dengue Aedes aegypti terhadap insektisida kelompok (organofosfat, karbamat, dan pyrethroid) di Provinsi Jawa Tengah dan Daerah Istimewa Yogyakarta. Buletin Penelitian Kesehatan. 2011; 39 (4): $176-89$.

6. Direktorat Jenderal Pengendalian Penyakit dan Penyehatan Lingkungan Departemen Kesehatan Republik Indonesia. Modul pelatihan bagi pengelola program pengendalian penyakit DBD di Indonesia. Jakarta: Direktorat Jenderal Pengendalian Penyakit dan Penyehatan Lingkungan 
Departemen Kesehatan Republik Indonesia; 2007.

7. Danis-Lozano R, Rodríguez MH, Hernández-Avila M. Gender-related family head schooling and Aedes aegypti larval breeding risk in Southern Mexico. Salud Publica de Mexico. 2002; 44 (3): 237-42.

8. Pramestuti N. Identifikasi vektor utama demam berdarah dengue dan sebaran virus Dengue di Kabupaten Banjarnegara. Laporan Akhir Penelitian Riset Pembinaan Kesehatan. Banjarnegara: Balai Litbang P2B2 Banjarnegara; 2012.

9. Pant CP, Self LS. Vector ecology and bionomics. Monograph on Dengue/Dengue Haemorrhagic Fever. WHO Reg Publ SEARO. 1999; 22: 121-38.

10. Minhas S, Sekhon H. Entomological survey for dengue vector in an institutional campus to determine whether potential of dengue outbreak exist. International Journal of Medical and Applied Science. 2013; 2 (4): 164-71.

11. Rohmah EA, Moehammadi N, Salamun. Fluktuasi populasi larva aedes aegypti pada berbagai jenis tempat perkembangbiakan di rumah penderita DBD. Jurnal Ilmiah Biologi. 2014; 2 (1): 40-9.

12. Sivagnaname N, Gunasekaran K. Need for an efficient adult trap for the surveillance of Dengue vectors. Indian Journal of Medical Research [serial on internet). 2012 [cited 2014 Jan 2]; 136 (5): 739-49. Available from: http://www.ijmr.org.in/text.asp?2012/136/5/739/105400.
13. Sambuaga JVI. Status entomologi vektor demam berdarah dengue di Kelurahan Perkamil Kecamatan Tikala Kota Manado Tahun 2011. JKL. 2011; 1 (1): 54-61.

14. World Health Organization dan Departemen Kesehatan Republik Indonesia. Pencegahan dan penanggulangan penyakit demam dengue dan demam berdarah. Jakarta: World Health Organization dan Departemen Kesehatan Republik Indonesia; 2003.

15. Vijayakumar K, Kumar TKS, Nujum ZT, Umarul F, Kuriakose A. A study on container breeding mosquitoes with special reference to aedes (stegomyia) aegypti and aedes albopictus in Thiruvananthapuram district, India. Jounal of Vector Born Disease. 2014; 51 (1): 27-32.

16. Food and Environmental Hygiene Department. Dengue fever [home page on internet]. 2014 [cited 2014 Jan 4]. Available from: http://www.fehd.gov.hk/english/safefood/dengue_fever/index.html.

17. Ikliludin A. Survei entomologis dan penghitungan mayaindex demam berdarah dengue di Kelurahan Ngampilan, Kecamatan Ngampilan, Kotamadya Yogyakarta [skripsi]. Yogyakarta: Fakultas Kedokteran Universitas Gadjah Mada; 2007.

18. Erlanger T, Keiser J, Utzinger J. Effect of dengue vector control interventions on entomological parameters in developing countries: a systematic review and meta-analysis. Medical and Veterenary Entomology. 2008; 22 (3): 203-21. 